\title{
Microbiota in Maintaining Normal Human Health
}

\author{
Shrihari $\mathrm{TG}^{1 *}$ and Shashi RekhaT ${ }^{2}$ \\ ${ }^{1}$ Department of oral medicine and radiology, Krishna devaraya college of dental sciences and hospital, India \\ ${ }^{2}$ Department of BioPhysics, Krishna devaraya college of dental sciences and hospital, India
}

Submission: February 23, 2017; Published: April 13, 2017

*Corresponding author: Shrihari TG, Assistant Professor, Department of Oral medicine and radiology, Krishna devaraya college of dental sciences and hospital, Bangalore-562157, Karnataka, India, Email: drshrihariomr@gmail.com

\begin{abstract}
Normal commensals of organisms present in human body is known as microbiota. Various organisms are present in a symbiotic environment such as bacterias, viruses, archea and eukaryotes, helps in maintaining normal health of human being. This article brief about the role of symbiotic microorganisms in maintaining normal health of human being.
\end{abstract}

Keywords: Microbiome; Probiotics; Prebiotics; Fecal transplantation; Dysbiosis

\section{Introduction}

Symbiotic microorganisms resides in normal homeostasis of human body is known as microbiota. Genomes of microbes in a particular ecosystem is called as microbiome. 100 trillion microbes are present in and on human body and 3.3 million nonredundant genes in the gut alone of a human microbiome, when compare to 22,000 genes in the entire human genome [1].

Diversity of microbes vary among individuals. 80-90\% human microbiota is different from each other in gut or on body surface, when compare to human genomes $99.9 \%$ are identical. Human microbiota mainly consists of bacterias, archaea, viruses and eukaryotes. Many of the microbes in the host are acquired from environment. Colonization of microorganisms starts at the time of vaginal delivery compared to caesarean delivery results in various health complications later such as impaired immune activity. Type of diet consumption influence on the composition and diversity of human gut microbiota [2-5].

Probiotics are live organisms such as lactobacillus species, bifidobacterium species, E Coli and streptococcus salivarius species confer health benefits to the host on adequate administration $\left(30 \times 10^{9} \mathrm{CFU} /\right.$ gram $)$. Which, alters the composition and functions of gut human microbiota by direct or secreting by product, used for treatment of various disorders. Probiotics containing products are milk, curd, milk products, probiotic containing tablets and powder. Prebiotics are nondigestible food ingredients such as human milk oligosaccharides, resistant starch, various soluble and insoluble dietary fibers, and xyloglucan, which enhance the activity of beneficial organisms composition, diversity and functions of especially human gut microbiota. Probiotics and prebiotics are used for the treatment of gastrointestinal disorders are irritable bowel syndrome, Antibiotic associated diarrhea, Crohn's disease, ulcerative colitis and also in allergic disorders, obesity, prevention of cancer, urinary tract infection, cardiovascular disorders, cholesterol reduction, psychological disorders. Because, of their antiinflammatory, immunostimulatory, antibacterial, maintaining intestinal mucosal integrity, antioxidant and antigenotoxic activity [4-10].

Fecal transplantation is used for treatment of various gastro intestinal disorders such as antibiotic associated diarrhea, irritable bowel syndrome, ulcerative colitis, and crohn's disease by altering microbiota of gut, administered viable bacteria through rectally via catheter colonoscopy, or oro-nasally through duodenoscope or naso-duodenal tube. Different types of fecal transplantation used are single donar from a close relative or friend without underlying disease and pathogens, multiple donors from stool banks, autologous fecal transplantation from same individual collected at disease free time, anaerobically cultivated feces from healthy donor $[10,11]$.

Hence, maintaining the homeostasis of symbiotic microbiota of human body is very important in maintaining normal health of human being is yet to be known. Microbial imbalance or altered adaption of microorganisms in our body, such as impaired microbiota is known as dysbiosis. 
Antibiotics not only destroys harmful bacteria's but also normal beneficial commensals of organisms in our body leads to many health disorders. Inadvertent use of antibiotics leads to many local or systemic adverse effects such as oral candidiasis(Acute atrophic candidiasis), adverse drug reactions, antibiotic associated diarrhea, and mainly antibiotic resistance. Which is a major cause of death worldwide because of organisms are resistant to antibiotics [11-13].

\section{Conclusion}

Antibiotic resistance is a major cause of concern, at present post antibiotic era and to find an alternative to antibiotics is in near future. Our future prospects to maintain human health largely depends on our microbiota of our body. Thorough understanding of composition, microbial diversity, their environment, factors affecting microbiota, function, interaction with other symbiotic organisms plays a very important role in health and diseases for future preventive and therapeutic strategy.

\section{References}

1. Karen PS, Jean-Michel A, Tore M, Saskia VH (2015) Manipulating the gut microbiota to maintain health and treat disease. Microb Ecol Health dis 26: 25877 .

2. Kumar M, Babaei P, Ji B, Nielsen J (2016) Human gut microbiota and healthy aging: Recent developments and future prospective. Nutr Healthy Aging 4(1): 3-16

3. Sun J, Chang EB (2014) Exploring gut microbes in health and disease; publishing the develop. Genes Genes Dis 1(2): 132-139.

This work is licensed under Creative

Commons Attribution 4.0 Licens

DOI : 10.19080/IJCSMB.2017.02.555577
4. Di Gioia D, Aloisiol, Mazzola G, Biavati B (2014) Bifidobacteria; Their impact on gut microbiota composition and their applications as probiotics in infants. ApplmicrobialBiotechnol 98(2): 557-63.

5. Human microbiome project consortium T (2012) Structure, function and diversity of the healthy human microbiome. Nature 483(7402): 207-214.

6. Zhang H, Sparks JB, karyalas V, Settlage R, Luo XM (2015) Host adaptive immunity altered gut microbiota. ISMEJ 9(3): 770-781.

7. Fouhy F, Ross RP, Fitzgerald GF, Stanton C, Colter PD (2012) Composition of the early intestinal microbiota; knowledge gaps and the use of high throughput sequencing to address these gaps. Gut microbes 3(3): 203220 .

8. Huurr A, Kalliomaki M, Rautava S, Rinne M, Salminen S, et al. (2008) Modes of delivery-Effects on gut microbiota and humoral immunity. Neonatology 93(4): 236-240.

9. Hill C, Gularner F, Reid G, Gibson GR, Merenstein DJ, Pot B, et al. (2014) Expert consensus document ; The international scientific association for probiotics and prebiotics consensus statement on the scope and appropriate use of the term probiotic. Nat Rev Gastroenterol Hepatol 11(8): 9-18.

10. Andoh A (2016) Physiological role of gut microbiota for maintaining human health. Digestion 93(3): 176-181.

11.Zeissig S, Blumberg RS (2014) Life at the beginning; Perturbation of the microbiota by antibiotics in early life and its role in health and disease. Nat immunol 15(4): 307-310.

12. Schulfer A, Blaser MJ (2015) Risks of antibiotic exposures early in life on the developing microbiome. PLoS Pathog 11(7): e1004903.

13. Ji B, Nielsen J (2015) From next- generation sequencing to systemic modeling of the gut microbiome. Front Genet 6: 219.

\section{Your next submission with Juniper Publishers} will reach you the below assets

- Quality Editorial service

- Swift Peer Review

- Reprints availability

- E-prints Service

- Manuscript Podcast for convenient understanding

- Global attainment for your research

- Manuscript accessibility in different formats

( Pdf, E-pub, Full Text, Audio)

- Unceasing customer service

Track the below URL for one-step submission https://juniperpublishers.com/online-submission.php 